\title{
T-lymphocyte cytotoxicity to HBsAg-coated target cells in hepatitis B virus infection
}

\author{
A. Alberti, ${ }^{1}$ G. ReAldi, F. BORTOlotti, AND A. M. Rigoli
}

From the Istituto di Medicina Clinica-Cattedra di Patologia Medica della Universita' di Padova, Padova, Italy

SUMMARY The cytotoxic effect of peripheral lymphocytes on chicken red blood cells (ChRBC) coated with purified hepatitis B surface antigen (HBsAg) has been studied as an in vitro parameter of cell-mediated immunity in acute and chronic infection with hepatitis B virus. Using this technique, the mean cytotoxic index of lymphocytes from patients with acute hepatitis B $(29 \cdot 13 \pm 20 \cdot 88)$ was significantly higher than that obtained with lymphocytes from control subjects $(6 \cdot 53 \pm 3 \cdot 75)$. Only $33.3 \%$ of the patients with $\mathrm{HBsAg}$-positive chronic active hepatitis exhibited lymphocyte cytotoxicity to HBsAg-coated target cells and the mean cytotoxic index $(11.66 \pm 6.60)$ was in these cases significantly lower than that found in acute hepatitis B. Healthy chronic carriers of $\mathrm{HBsAg}$ failed to show lymphocyte cytotoxicity to target cells. The effector cells detected in acute hepatitis B by this in vitro assay have been demonstrated to be T-lymphocytes, as T-cell depleted subpopulations lacked cytotoxic activity. Target cell lysis could be blocked by addition of HBsAg-coated unlabelled ChRBC as well as of purified HBsAg in the culture tubes. It is suggested that damage to the liver cells in acute hepatitis B is related to the presence of cytotoxic T-lymphocytes reacting with $\mathrm{HBs} \mathrm{Ag}$ on the surface of infected hepatocytes. An inadequate lymphocyte response to the antigen may be responsible for the persistence of the infection in the liver with varied clinical manifestations and associated hepatic lesions.

The causes of hepatocellular damage occurring in patients with $\mathrm{HBsAg}$-positive inflammatory liver disease have not yet been clarified. Hepatitis B virus itself does not appear to induce liver lesions as large amounts of HBsAg are detected in the hepatocytes in healthy chronic carriers (Hadziyannis et al., 1972). Recent results suggest that cell-mediated immunity may play an important role in the pathogenesis of the disease by either of two processes. The first is mediated by an immunological reaction directed against viral antigens or viral induced neoantigens and the second is an autoimmune reaction against liver specific membrane proteins. Dudley et al. (1972) suggested that in hepatitis B infection the liver cell necrosis could be related to specifically sensitised lymphocytes reacting with viral antigens on the surface of infected hepatocytes. This hypothesis is supported by the demonstration of cellmediated immune reactions to $\mathrm{HBsAg}$ in patients

${ }^{1}$ Address for correspondence: Dott. Alfredo Alberti, Istituto di Medicina Clinica, Cattedra di Patologia Medica, via Giustiniani 1, 35100 Padova, Italy. Received for publication 30 May 1977 with acute hepatitis B (Gerber et al., 1974; Lee et al., 1977); in addition, we have recently identified, by immunofluorescence, the presence of $\mathrm{HBsAg}$ at the hepatocyte surface in the early phase of the disease (Alberti et al., 1976). On the other hand, studies on cellular sensitisation to the antigen in HBsAg chronic carriers, either with or without liver disease, gave controversial results (Gerber et al., 1974; De Moura et al., 1975; Lee et al., 1975) and HBsAg could not be localised at the liver cell surface (Alberti et al., 1976). Recent reports pointed out the possibility that the pathogenesis of chronic active hepatitis, both HBsAg-positive and negative, may be related to an antibody-dependent, K-cell mediated cellular cytotoxicity directed against liver specific membrane antigens (Cochrane et al., 1976).

So far, cell-mediated immunity to $\mathrm{HBsAg}$ has been studied using the leucocyte migration inhibition and the lymphocyte transformation tests and its role in the clearance of the virus from the liver has been emphasised. The direct cytotoxic effect of lymphocytes sensitised to this antigen has not yet been evaluated. In this report we have investigated 
whether peripheral lymphocytes from patients with HBsAg-associated acute and chronic hepatitis, as well as from healthy carriers of the antigen, are able to cause the lysis of $\mathrm{HBsAg}$-coated target cells. Chicken red blood cells (ChRBC) labelled with ${ }^{51} \mathrm{Cr}$ and coated with purified $\mathrm{HBsAg}$ were used to detect the presence of cytotoxic lymphocytes. In an attempt to identify the cytotoxic effector cell in this system we have performed cell fractionation experiments.

\section{Methods}

\section{PATIENTS}

Four groups were examined: (1) 15 healthy volunteers without a history of liver disease or of exposure to hepatitis B virus contaminated materials; absence of sensitisation to $\mathrm{HBsAg}$ had been ascertained in each of these subjects by RIA for anti-HBs and by leucocyte migration inhibition test with purified HBsAg (Realdi et al., 1976); (2) 23 patients with acute hepatitis $B$ tested three to five weeks from the onset of jaundice; (3) 12 untreated patients with HBsAg-positive chronic active hepatitis; and (4) 10 healthy chronic carriers of $\mathrm{HBsAg}$. In groups 3 and 4 the diagnosis had been confirmed by liver biopsy in each case.

\section{TECHNIQUES}

Lymphocyte preparation and $T$ and $B$ cell separation Twenty millilitres of venous blood were mixed with 100 units phenol-free heparin and with $1 \mathrm{ml} 5 \%$ dextran solution (molecular weight 200.000). After sedimentation of the red blood cells, the leucocyterich plasma was incubated in a cotton-wool column at $37^{\circ} \mathrm{C}$ for 15 minutes to remove macrophages. Non-adherent cells were eluted with $15 \mathrm{ml}$ of tissue culture medium (Eagle's medium-Serva- $\mathrm{pH} 7 \cdot 4$ containing $5 \%$ of foetal calf serum-FCS DifcoLab.) and centrifuged over a Ficoll-Triosil density gradient at $400 \mathrm{~g}$ for 30 minutes. The lymphocytes at the interface were collected, washed three times in tissue culture medium and suspended at a concentration of $2.5 \times 10^{6} / \mathrm{ml}$.

B-cell enriched fractions were prepared by mixing $5 \mathrm{ml}$ of peripheral lymphocytes $\left(2.5 \times 10^{6} / \mathrm{ml}\right.$ in medium containing $30 \%$ FCS) with $5 \mathrm{ml}$ of sheep red blood cells $\left(1 \times 10^{8} / \mathrm{ml}\right.$ in medium-30\% FCS $)$. The mixture was immediately centrifuged at $200 \mathrm{~g}$ for five minutes, incubated at $4^{\circ} \mathrm{C}$ for one hour and, after resuspension of the pellet, centrifuged on a Ficoll-Triosil gradient at $400 \mathrm{~g}$ for 30 minutes to remove E-rosette forming cells. The interface lymphocytes were collected, washed three times, and suspended at a concentration of $2.5 \times 10^{6} / \mathrm{ml}$ in medium.
T-lymphocytes were prepared by mixing $2 \mathrm{ml}$ of peripheral lymphocytes $\left(2.5 \times 10^{6} / \mathrm{ml}\right)$ with $2 \mathrm{ml}$ of a $1 \%(\mathrm{vol} / \mathrm{vol})$ suspension of sheep red blood cells sensitised with antibody and complement as proposed by Stjernswärd et al. (1972). The mixture was centrifuged at $200 \mathrm{~g}$ for five minutes, incubated for 30 minutes at $37^{\circ} \mathrm{C}$ and the EAC-rosetted cells were removed by centrifugation on Ficoll-Triosil (400 g, 30 minutes). T-lymphocytes were collected at the interface, washed three times and suspended at a concentration of $2.5 \times 10^{6} / \mathrm{ml}$ in tissue culture medium.

Purity of the two separated lymphocyte populations was tested, checking the ability of these cells to form both $\mathrm{E}$ and EAC rosettes. B-cell fractions contained $5-11 \%$ of T-cells and T-lymphocytes were contaminated with $3-6 \%$ of EAC-rosette forming cells.

\section{Purified hepatitis B surface antigen}

Coating of target cells as well as blocking experiments were carried out using purified $\mathrm{HBsAg}$, containing a mixture of ad and ay subtypes, prepared from plasma samples of healthy carriers by a three-step procedure involving isopycnic banding in $\mathrm{CsCl}$ density gradients and zonal centrifugation on sucrose gradients (Gerin et al., 1971). The antigen was dialysed extensively against saline at $4{ }^{\circ} \mathrm{C}$. The optical density at $280 \mathrm{~nm}$ wavelength of the purified antigen was 2.05 with a protein content of $0.550 \mathrm{mg} / \mathrm{ml}$ as calculated by the extinction coefficient $\mathrm{E} 0 \cdot 1 \% / 1 \mathrm{~cm}=3 \cdot 73$. This preparation gave a single band in immunodiffusion at a maximum dilution of $1: 8$ when tested against a rabbit anti-HBs serum and, when concentrated five-fold, no precipitin band with antisera against human plasma proteins.

\section{Preparation of target cells}

These were chicken red blood cells labelled with ${ }^{51} \mathrm{Cr}$ and coated with purified $\mathrm{HBsAg}$ by the chromic chloride method. Five millilitres of blood were collected from 3 month old White Leghorn chickens; after the addition of 10 units of heparin the erythrocytes were washed three times ( $200 \mathrm{~g}$ for 10 minutes) and suspended in normal saline at a concentration of $2 \times 10^{8} / \mathrm{ml} ; 0.1 \mathrm{ml}$ of this preparation was incubated with $0.1 \mathrm{ml} \mathrm{Na}_{2}{ }^{5} \mathrm{CrO}_{4}(1 \mathrm{mCi} / \mathrm{ml}$, isotonic solution, Radiochemical Centre, Amersham) at $37^{\circ} \mathrm{C}$ for one hour. The cells were washed three times and suspended in normal saline at $40 \%$ (vol/vol). To coat these ${ }^{51} \mathrm{Cr}-\mathrm{ChRBC}$ with $\mathrm{HBsAg}$, $100 \mu \mathrm{l}$ purified $\mathrm{HBsAg}(550 \mu \mathrm{g} / \mathrm{ml}$ in saline) were mixed with $50 \mu \mathrm{l} 40 \%$ suspension of ${ }^{51} \mathrm{Cr}-\mathrm{ChRBC}$ and with $50 \mu 13.75 \mathrm{mM}$ chromic chloride in $5 \mathrm{ml}$ sterile plastic tubes (Falcon). These were found to be the best conditions of coating by 'checkerboard' 
experiments with different dilutions of antigen and of chromic chloride, as proposed by Vyas et al. (1972) (see Results section and Table 1). The mixture was incubated at room temperature for five minutes and centrifuged at $150 \mathrm{~g}$ for one minute. The ChRBC were then washed three times ( $150 \mathrm{~g}$ for five minutes) in saline, counted, and kept in pellet at $4^{\circ} \mathrm{C}$ until required. Target cells were used in the cytotoxic test within 12 hours from preparation and suspended at $10^{5} / \mathrm{ml}$ in Eagle's medium plus $5 \%$ FCS immediately before use. The actual coating of each preparation of target cells was tested by agglutination assay using a standard anti-HBs serum.

\section{Cytotoxic assay procedure}

Five hundred microlitres of lymphocytes $(2.5 \times$ $10^{6} / \mathrm{ml}$ ) were incubated with $500 \mu \mathrm{l} \mathrm{HBsAg-coated}$ ${ }^{51} \mathrm{Cr}$-ChRBC $\left(10^{5} / \mathrm{ml}\right)$ in $5 \mathrm{ml}$ sterile tissue culture tubes (Falcon). Control cultures containing lymphocytes and uncoated ${ }^{51} \mathrm{Cr}-\mathrm{ChRBC}$ were set up in order to evaluate the spontaneous lymphocyte cytotoxicity. Spontaneous isotope release was estimated culturing $0.5 \mathrm{ml}$ of target cells with $0.5 \mathrm{ml}$ of normal ChRBC $\left(2.5 \times 10^{6} / \mathrm{ml}\right)$ in place of lymphocytes. Maximum isotope release was calculated by adding $1 \mathrm{ml}$ distilled water to $5 \times 10^{4}$ target cells. All cultures were set up in triplicate and incubated at $37^{\circ} \mathrm{C}$ for 24 hours in air, $5 \% \mathrm{CO}_{2}$. After incubation, the tubes were centrifuged at $200 \mathrm{~g}$ for 10 minutes and $0.5 \mathrm{ml}$ supernatant removed. Counts per minute $(\mathrm{cpm})$ in $0.5 \mathrm{ml}$ supernatant and in $0.5 \mathrm{ml}$ sediment were determined in a well-type gamma counter (Packard). Isotope release $(\%)$ in each experiment was estimated as follows:

$\frac{\text { supernatant } \mathrm{cpm} \times 2}{\text { supernatant } \mathrm{cpm}+\text { sediment } \mathrm{cpm}} \times 100$

The results, expressed as cytotoxic index, were calculated as follows:

experimental $\%$ isotope release - spontaneous $\%$ isotope release/maximum $\%$ isotope release spontaneous $\%$ isotope release $\times 100$.

Table 1 Titration experiments to determine optimal conditions for coating ChRBC with purified HBsAg by $\mathrm{CrCl}_{3}$ method

\begin{tabular}{llllll}
\hline $\begin{array}{l}\text { Purified } \mathrm{HBs} \mathrm{Ag} \\
\text { (protein concentration) }\end{array}$ & \multicolumn{5}{c}{ Dilutions of $\mathrm{CrCl}_{3}$ stock solution $(0.0375 \mathrm{M})$} \\
\cline { 2 - 6 }$(\mu \mathrm{g} / \mathrm{ml})$ & $1: 1$ & $1: 5$ & $1: 10$ & $1: 20$ & Saline \\
\hline 550 & n.s. & n.s. & 512 & 8 & 0 \\
275 & n.s. & n.s. & 256 & 8 & 0 \\
$137 \cdot 5$ & n.s. & n.s. & 16 & 0 & 0 \\
$68 \cdot 75$ & n.s. & n.s. & 16 & 0 & 0 \\
Saline & n.s. & n.s. & 0 & 0 & 0 \\
\hline
\end{tabular}

n.s. = non-specific agglutination.

Results are given as reciprocal of the highest dilution of anti-HBs serum showing agglutination.

\section{Blocking experiments}

Two procedures were performed in an attempt to block lymphocyte cytotoxicity, adding (1) $55 \mu \mathrm{g}$ purified $\mathrm{HBsAg}$ in the culture tubes, or (2) an excess of unlabelled HBsAg-coated ChRBC to target cells ( $3: 1$ ratio); the results were compared with those that were obtained when normal ChRBC and target cells were mixed in the same ratio.

\section{Results}

Different concentrations of $\mathrm{HBsAg}$ and dilutions of the stock solution of chromic chloride $(0.0375 \mathrm{M})$ were tested to determine optimum conditions for coating ChRBC with HBsAg (Table 1). Antigen concentration lower than $275 \mu \mathrm{g} / \mathrm{ml}$ failed to give reliable coating as determined on the basis of agglutination by specific anti-HBs sera. Dilutions of the $\mathrm{CrCl}_{3}$ stock solution lower than 1:10 gave nonspecific aggregation of ChRBC. In all experiments coating of ChRBC was obtained using $550 \mu \mathrm{g} / \mathrm{ml}$ $\mathrm{HBsAg}$ and 1:10 dilutions of the $\mathrm{CrCl}_{3}$ stock solution.

In 24 hour cultures spontaneous isotope release from HBsAg-coated ChRBC varied between 4 and $11 \%$ and the mean release was $8.11 \pm 2.05$ (mean $\pm \mathrm{SD}$ ); maximum isotope release varied between 77 and $91 \%$, the mean being $84 \cdot 13 \pm 4 \cdot 44$.

The mean spontaneous cytotoxic indexes against uncoated ChRBC detected in patients with acute hepatitis B $(6 \cdot 11 \pm 4 \cdot 01)$, chronic active hepatitis $(5.88 \pm 5 \cdot 11)$, and in healthy carriers of HBsAg $(6 \cdot 28 \pm 5 \cdot 22)$ showed no significant differences when compared with the value obtained in control subjects $(5 \cdot 42 \pm 3 \cdot 33)$.

The cytotoxic indexes obtained with peripheral lymphocytes from controls and patients tested against HBsAg-coated target cells are shown in Fig. 1. Lymphocytes from controls gave a cytotoxic index between 2 and 12 and the mean was $6.53 \pm$ 3.75. The upper limit of normal range (14) was taken as 2 SD above the mean in controls and each patient who showed an index higher than this value was considered to be positive. Lymphocytes from $65.2 \%$ of acute hepatitis B patients were cytotoxic to target cells. The index varied between 3 and 66 and the mean cytotoxic index was $29 \cdot 13 \pm 20 \cdot 88$; the difference between this value and the mean cytotoxic index of controls was statistically significant $(\mathrm{P}<0.001)$. In HBsAg-positive chronic active hepatitis, $33.3 \%$ of the cases tested had lymphocytes cytotoxic to target cells; the index varied from 3 to 23 and the mean was $11.66 \pm 6.60$; this value was significantly higher than that obtained in controls $(\mathrm{P}<0.05)$ but lower than the mean cytotoxic index of acute hepatitis patients $(\mathrm{P}<0.005)$. None of the 


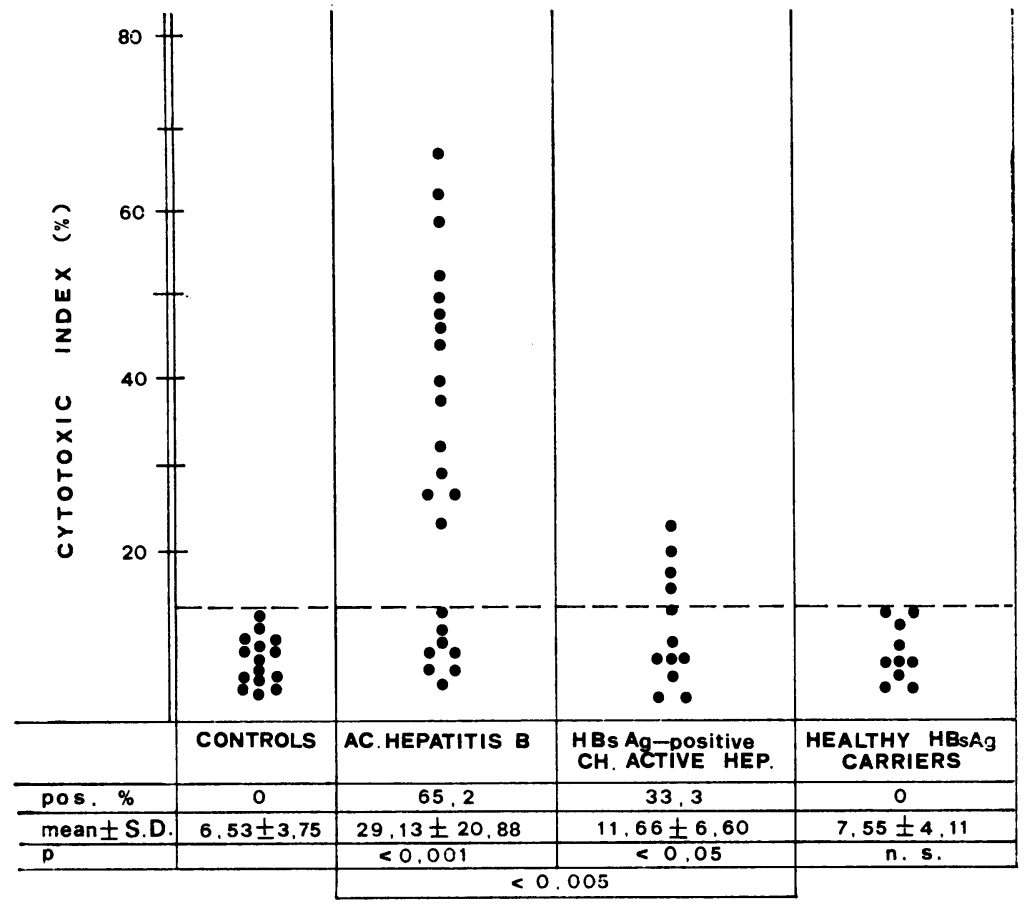

Fig. 1 Cytotoxicity to HBsAgcoated chicken red blood cells of lymphocytes from normal subjects and from patients. Broken line: upper limit of normal range, taken as $2 S D$ above mean obtained in controls.

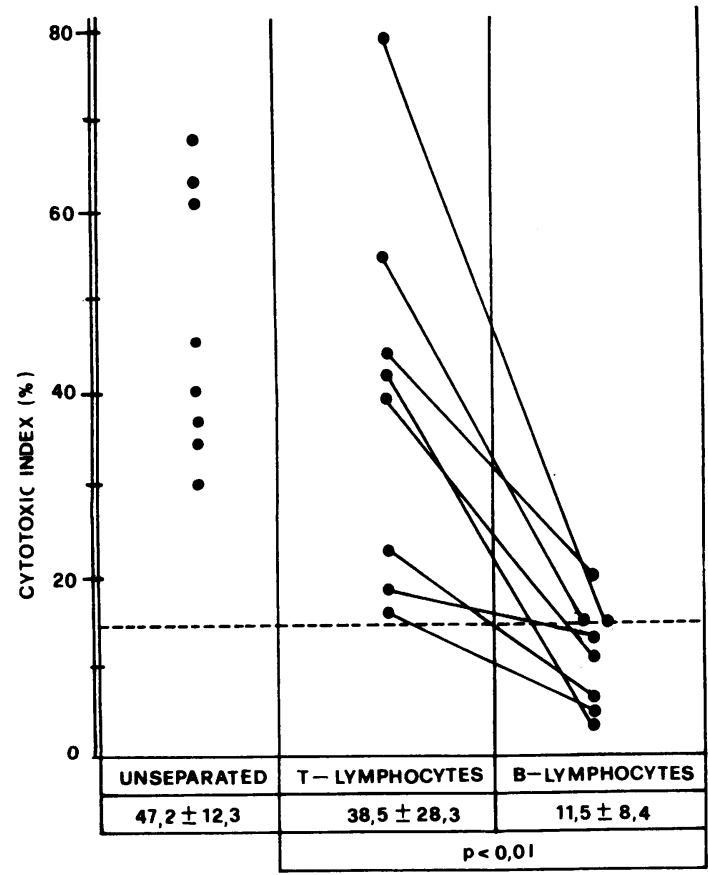

Fig. 2 The effect of separated $T$ - and B-cell populations on HBsAg-coated target cells in patients with acute hepatitis B. Broken line: upper limit of normal range. healthy chronic carriers of HBsAg showed lymphocyte cytotoxicity to target cells; the mean cytotoxic index in these cases $(7 \cdot 55 \pm 4 \cdot 11)$ was not significantly different from that of controls.

Purified T and B cell populations were prepared in eight patients with acute hepatitis B in whom unseparated lymphocytes had been demonstrated to be cytotoxic to HBsAg-coated target cells (Fig. 2); in all cases T-lymphocytes enriched fractions caused a significant release of isotope from target cells, while B-cells were weakly cytotoxic only in one case. The difference between the mean cytotoxic index for $T(38.5 \pm 28 \cdot 3)$ and $B(11.5 \pm 8.4)$ enriched populations was significant at $\mathbf{P}<0.01$. T-cell cytotoxicity was significantly reduced after the addition of HBsAg-coated unlabelled ChRBC (unlabelled/ ${ }^{51} \mathrm{Cr}$ labelled ChRBC ratio 3/1) as well as of purified HBsAg ( $55 \mu \mathrm{g} /$ tube) to the culture tubes, while no changes in the cytotoxic index were observed when normalChRBCwere mixed with target cells (Table 2).

\section{Discussion}

The cytotoxic activity of lymphocytes against target cells coated with specific antigens has been defined as an in vitro parameter of cell-mediated immunity (Perlmann and Holm, 1969; Henney, 1970). These reactions may be mediated by $T$ and non-T $(K)$ lymphocytes and may be the cause of immuno- 
Table 2 Blocking experiments on T-lymphocyte mediated cytotoxicity against HBsAg-coated ChRBC in patients with acute hepatitis $B$

\begin{tabular}{lll}
\hline Culture conditions & No. & $\begin{array}{l}\text { Mean cytotoxic } \\
\text { index }\end{array}$ \\
\hline T-lymphocytes/target cells $(25: 1)$ & 8 & $38 \cdot 5 \pm 28 \cdot 3$ \\
T-lymphocytes/target cells $(25: 1)$ & 8 & $16 \cdot 37 \pm 16 \cdot 11$ \\
$\quad+$ purified HBsAg $(55 \mu \mathrm{g} /$ tube $)$ & & $(\mathrm{P}<0 \cdot 05)$ \\
$\begin{array}{c}\text { T-lymphocytes/target cells }(25: 1) \\
\text { + unlabelled HBsAg-coated }\end{array}$ & 8 & $(\mathrm{P}<0.66 \pm 7 \cdot 77$ \\
$\begin{array}{c}\text { ChRBC }(3: 1 \text { to target cells) } \\
\text { T-lymphocytes/target cells }(25: 1) \\
\text { + normal ChRBC }(3: 1 \text { to target } \\
\text { cells) }\end{array}$ & 8 & $36.44 \pm 30.23$ \\
\hline
\end{tabular}

pathological tissue damage when membrane antigens are involved.

Following the demonstration of $\mathrm{HBsAg}$ at the liver cell surface in patients with acute hepatitis B (Alberti et al., 1976), we investigated the in vitro effect of lymphocytes on HBsAg-coated target cells in acute and chronic hepatitis B virus infection, in order to define further the role of cell-mediated immunity in the pathogenesis of the disease.

The results obtained show that cytotoxic lymphocytes were present in the peripheral blood of $65.2 \%$ of the patients tested three to five weeks after the onset of acute hepatitis B. These observations are in agreement with those obtained using other in vitro assay systems for cell-mediated immunity, such as lymphocyte transformation (Yeung Laiwah et al., 1973), and leucocyte migration inhibition tests (Gerber et al., 1974; De Moura et al., 1975; Lee et al., 1977). In contrast with these methods, which often seem to reflect both humoral and cellular immunity, the cytotoxic test allowed us to identify the lymphocyte subpopulation involved in the reaction, as purified T-lymphocytes, but not B-cells, were able to cause the lysis of HBsAg-coated target cells. Lymphocyte killing could be blocked with unlabelled HBsAg-coated ChRBC and with purified HBsAg. These results suggest that the effector cells in this in vitro model are cytotoxic T-lymphocytes specifically sensitised to HBsAg.

Several authors have suggested that, in acute hepatitis B, liver cell may be initiated by sensitised T-lymphocytes that recognise $\mathrm{HBsAg}$ at the surface of infected hepatocytes (Dudley et al., 1972; Eddleston and Williams, 1974). Such a reaction may be itself cytotoxic or induce a B-cell response to liver specific membrane antigens, responsible for an antibody dependent cell-mediated cytotoxicity. Our results support both these possibilities, showing for the first time that in acute hepatitis B sensitised $T$ cells are produced which are able to destroy $\mathrm{HBsAg}$ coated target cells.

However, direct evidence of a pathogenetic role of these reactions in causing liver cell damage should be obtained by testing with this cytotoxicity technique patients in the prodromic or very early phase of the disease, as only at that time is HBsAg detected in the liver on the hepatocyte membrane (Alberti et al., 1976).

Lymphocyte cytotoxicity to HBsAg coated ChRBC was detected in $33.3 \%$ of the cases with HBsAgpositive chronic active hepatitis, but the mean cytotoxic index obtained was statistically below the value found in acute hepatitis $B$. Healthy carriers of the antigen failed to show cytotoxicity to target cells. Ton: $_{3}$ et al. (1975) described a partial lymphocyte transformation with $\mathrm{HBsAg}$ in patients with chronic active hepatitis and no transformation in healthy carriers. Our study is in agreement with these results suggesting that an incomplete destruction of infected hepatocytes with persistent viral infection in the liver may occur in these patients as a consequence of an inadequate immune response to the surface antigen. The complete unresponsiveness to $\mathrm{HBsAg}$ found in carriers with a normal liver may explain the absence of lesions.

The effector cells responsible for the cytotoxic reaction detected in $\mathrm{HBsAg}$-positive chronic active hepatitis have not been identified in this study. It could be postulated that, in these cases, as in acute hepatitis $\mathrm{B}$, the reaction is $\mathrm{T}$-cell mediated, though being impaired as a consequence of T-cell defect or hindered by blocking factors; on the other hand, we cannot exclude the possibility that other cells, mainly $\mathrm{K}$ cells, may be involved in the cytotoxic reaction in these patients. This possibility must be considered, as in $\mathrm{HBsAg}$-positive chronic active hepatitis IgG bound to the hepatocyte membrane have been detected and their presence correlates tightly with the activity of the disease (Hopf et al., 1975; Alberti et al., 1976); there is evidence supporting the assumption that these cytophilic antibodies are directed against antigens that are different from normal liver specific membrane proteins (Alberti et al., 1977). These immunoglobulins may interfere with the T-cell mediated clearance of infected liver cells but may also induce an antibody-dependent cellular (K-cells) cytotoxicity. Further studies are necessary to better characterise the $\mathrm{HBs} A g$-sensitised cytotoxic cell population in patients with antigenpositive chronic active hepatitis and its role in the pathogenesis of the disease.

This work was supported in part by a grant (C.T. 74 00239.04) from Consiglio Nazionale delle Ricerche, Rome, Italy.

\section{References}

Alberti, A., Realdi, G., Tremolada, F., Spina, G. P. (1976). Liver cell surface localization of hepatitis B antigen and of 
immunoglobulins in acute and chronic hepatitis and in liver cirrhosis. Clinical and Experimental Immunology, 25, 396-402.

Alberti, A., Realdi, G., Tremolada, F., Rigoli, A. M., and Fattovich, G. (1976). Presenza di HBsAg e di IgG sulla membrana di cellule epatiche in pazienti con epatite acuta e cronica. Minerva Gastroenterologica, 22, 235-240.

Cochrane, A. M., Moussouros, A., Thomson, A. D., Eddleston, A. L. W. F., and Williams, R. (1976). Antibodydependent cell-mediated (K-cell) cytotoxicity against isolated hepatocytes in chronic active hepatitis. Lancet, 1, 441-444.

De Moura, M. C., Vernace, S. J., and Paronetto, F. (1975). Cell-mediated immune reactivity to hepatitis B surface antigen in liver diseases. Gastroenterology, 69, 310-317.

Dudley, F. J., Fox, R. A., and Sherlock, S. (1972). Cellular immunity and hepatitis-associated Australia antigen liver disease. Lancet, 1, 723-726.

Eddleston, A. L. W. F., and Williams, R. (1974). Inadequate antibody response to HBAg or suppressor T-cell defect in development of active chronic hepatitis. Lancet, 2, 15431545.

Gerber, M. J., Phuangsab, A., Vittal, S. B. V., Dourdourekas, D., Steigmann, F., and Clowdus, B. F. (1974). Cellmediated immune response to hepatitis $\mathbf{B}$ antigen in patients with liver disease. American Journal of Digestive Diseases, 19, 637-643.

Gerin, J. L., Holland, P. V., and Purcell, R. H. (1971). Australia antigen: large-scale purification from human serum and biochemical studies of its proteins. Journal of Virology, 7, 569-576.

Hadziyannis, S., Moussouros, A, Vissoulis, C., and Afroudakis, A. (1972). Cytoplasmic localisation of Australia antigen in the liver. Lancet, 1, 976-979.

Henney, C. S. (1970). A cytolitic system for the in vitro detection of cell-mediated immunity to soluble antigen. Journal of Immunology, 105, 919-927.

Hopf, U., Arnold, W., Meyer zum Büschenfelde, K. H.,
Förster, E., and Bolte, J. P. (1975). Studies on the pathogenesis of chronic inflammatory liver diseases. I. Membrane fixed IgG on isolated hepatocytes from patients. Clinical and Experimental Immunology, 22, 1-8.

Lee, W. M., Reed, W. D., Mitchell, C. G., Galbraith, R. M., Eddleston, A. L. W. F., Zuckerman, A. J., and Williams, R. (1975). Cellular and humoral immunity to hepatitis B surface antigen in active chronic hepatitis. British Medical Journal, 1, 705-708.

Lee, W. M., Reed, W. D., Osman, C. G., Vahrman, J., Zuckerman, A. J., Eddleston, A. L. W. F., and Williams, R. (1977). Immune responses to the hepatitis B surface antigen and liver-specific lipoprotein in acute type B hepatitis. Gut, 18, 250-257.

Perlmann, P., and Holm, G. (1969). Cytotoxic effects of lymphoid cells in vitro. Advances in Immunology, 11, 117-193.

Realdi, G., Bortolotti, F., Alberti, A., Fattovich, G., and Ongaro, G. (1976). Infezione da virus dell'epatitie B e risposta immunitaria dell'ospite. Bollettino Istituto Sieroterapico Milanese, 55, 323-334.

Stjernswärd, J., Jondal, M., Vanky, F., Wigzell, H., and Sealy, R. (1972). Lymphopenia and change in distribution of human $B$ and $T$ lymphocytes in peripheral blood induced by irradiation for mammary carcinoma. Lancet, 1 , 1352-1356.

Tong, M. J., Wallace, A. M., Peters, R. L., and Reynolds, T. B. (1975). Lymphocyte stimulation in hepatitis B infections. New England Journal of Medicine, 293, 318-322.

Vyas, G. N., Fudenberg, H. H., Pretty, H. M., and Gold, E. R. (1968). A new rapid method for genetic typing of human immunoglobulins. Journal of Immunology, 100, 274-279.

Yeung Laiwah, A. A. C., Chaudhuri, A. K. R., and Anderson, J. R. (1973). Lymphocyte transformation and leucocyte migration-inhibition by Australia antigen. Clinical and Experimental Immunology, 15, 27-34. 